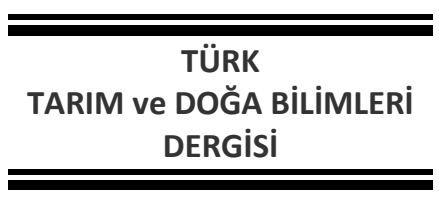

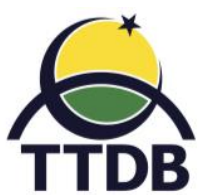

www.dergipark.gov.tr/turkjans

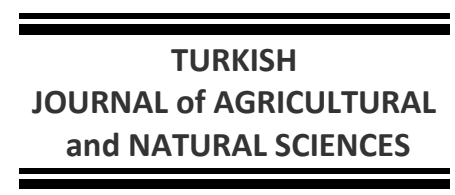

Araştırma Makalesi

\title{
Ekmeklik Buğdayda (Triticum aestivum L.) Ekim Sıklığının Tane İriliği ve Bazı Kalite Parametreleri Üzerine Etkisinin İncelenmesi ${ }^{a}$
}

\author{
Ali Cevat SÖNMEZ ${ }^{1 *}$, Murat OLGUN² \\ ${ }^{1}$ Geçit Kuşağı Tarımsal Araştırma Enstitüsü, Ziraat Cad. No: 396 Tepebaşı, Eskişehir. \\ ${ }^{2}$ Eskişehir Osmangazi Üniversitesi, Ziraat Fakültesi, Tarla Bitkileri Bölümü Odunpazarı, Eskişehir. \\ *Sorumlu Yazar: alicevat.sonmez@tarimorman.gov.tr
}

Geliş Tarihi: 05.04.2019

Düzeltme Geliş Tarihi: 07.08.2019

Kabul Tarihi: 23.08.2019

Özet

Bu araştırmada 4 farklı (350, 500, 650 ve 800 tohum m²) ekim sıklığı (ES) uygulamasının 6 ekmeklik buğday çeşidinin (Alpu01, Atay85, Bezostaja1, Harmankaya99, Sönmez01 ve Sultan95) bazı kalite özelliklerine etkisinin belirlenmesi amaçlanmıştır. Araştırma 2012-2013 ve 2013-2014 yıllarında Geçit Kuşağı Tarımsal Araştırma Enstitüsü Eskişehir Merkez yerleşkesinde yürütülmüştür. Denemeler tesadüf bloklarında faktoriyel deneme deseninde 3 tekerrürlü olarak kuru (yağışa bağımlı) ve sulu koşullarda yürütülmüştür. Çalışmada iri tane oranı (iTO), ufak tane oranı (UTO), bin tane ağırlığı (BTA), hektolitre ağırlığı (HLA), tane protein oranı (TPO), kuru gluten (KGL), zeleny sedimentasyon (ZSD) ve sertlik değeri (SRD) gibi kalite unsurları incelenmiştir. Araştırma sonuçlarına göre ES uygulamalarının kuru koşullarda ITO, UTO, BTA ve SRD unsurlarına etkisi önemli $(p<0.01)$ bulunurken, sulu koşullarda sadece BTA unsuruna etkisi önemli $(p<0.01)$ bulunmuştur. ES artışları iki çevre de de iTO ve BTA değerlerini olumsuz etkilemiştir. Çeşitler arası farklılıklar ise araştırılan tüm parametrelerde $(p<0.01)$ önemli bulunmuştur. Sönmez01 ve Bezostaja1 çeşitleri ITO, BTA ve HLA açısından; Bezostaja1 çeşidi ZSD, TPO ve KGL açısından; Sultan 95 ise UTO ve SRD açısından öne çıkmıştır. Gerek kuru gerekse sulu çevrede ITO ile UTO ve SRD arasındaki olumsuz korelasyon; BTA, HLA, KGL ve ZSD arasında ise olumlu korelasyonun önemli $(p<0.01)$ olduğu belirlenmiştir.

Anahtar kelimeler: Bitki sıklığı, kalite özellikleri, kuru, sulu.

\section{Examining of The Effect of Sowing Densities on Grain Size and Some Quality Parameters in Bread Wheat (Triticum aestivum L.)}

\begin{abstract}
The trials were carried out in Eskişehir central campus of the Transitional Zone Agricultural Research Institute for two years in 2012-13 and 2013-14 growing years. The researchs are carried out in the randomized block design with 3 replication in rainfed and irrigated conditions. There are investigated effect of different level $\left(350,500,650\right.$ and 800 tohum $\mathrm{m}^{-2}$ ) of sowing density application on six bread wheat varieties (Alpu01, Atay85, Bezostaja1, Harmankaya99, Sönmez01 and Sultan95). It was aimed that to determine of the sowing densities to effects on large grain ratio (LGR), small grain ratio (SGR), 1000 grain weight (TGW), test weight (TW), grain protein content (GPC), gluten content (GC), zeleny sedimentation (ZS) and hardness value (HV) parameters. According to results of the study, while the effect of sowing densities applications in rainfed conditions are significant ( $p<0.01)$ on LGR, SGR, TGW and HV components, the effect on only TGW parameter in irrigated conditions is significant ( $p$ $<0.01)$. The sowing density increases are affected negatively both LGS and TGW values. The differences between the cultivars were significant $(p<0.01)$ in all parameters. Sönmez01 and Bezostaja1 in terms of LGR, TGW and TW;
\end{abstract}


Bezostaja1 in terms of ZS, PC and GC; Sultan95 in terms of HV were prominent. It is seen that negative relationship is significant $(p<0.01)$ between LGR with SGR and HV in both rainfed and irrigated conditions. There are positive correlations between TGW with the parameters TW, GC and ZS is significant $(p<0.01)$.

Key words: Plant density, quality characteristics, rainfed, irrigated.

\section{Giriş}

Ekmeklik buğday, (Triticum aestivum L.) antik çağlardan beri tarımı yapılan ve insan yaşamı için stratejik önemi olan bitkilerden biri olarak bilinmektedir. 2050 yıllarında Dünya nüfusunun 9.7 milyarı (Anonim, 2018a), Türkiye nüfusunun ise 105 milyonu (Anonim, 2018b) aşması beklenmektedir. 2017 yılında 182 kg kişi başı tüketim ile dünyada en fazla buğday tüketimi yapılan ülkelerden biri olan Türkiye de 2018 yılında 7,3 milyon hektar ekim alanında 20 milyon ton üretim yapılmıştır (Anonim, 2019). Dünyada nüfus artışına paralel olarak buğdaya olan talebin her yıl \% 2 oranında artacağı öngörülmüştür (Alexandratos ve Bruinsma, 2012). Ülkemizde de buğdaya olan talebin her yıl artması beklenmektedir. Bu talebin karşılanabilmesi ancak yüksek verimli, biyotik ve abiyotik streslere dayanıklı çeşitlerin geliştirilerek üretime alınması ve optimum yetiştirme tekniklerinin tam olarak uygulanması ile mümkün olabilecektir. Ekim sıklığı (ES) önemli yetiştirme tekniği uygulamalarından biri olup yüksek verim elde etmek için, genotip ve çevresel etkilere göre değişmekte olduğundan, ekilecek tohumun optimum miktarının mutlaka ortaya koyulması gerekmektedir (Chen ve ark., 2008). Bazı araştırmacılar tane iriliğinin bazı kalite unsurlarını çimlenme, çıkış hızı ve verim öğelerini önemli oranda etkilediği için ıslah çalışmalarında dikkate alınması gerektiğini belirtmişlerdir (Akinci ve ark., 2008; Aydoğan ve ark., 2015). Yine Karaduman ve ark. (2017) araştırmada incelenen parametrelerden tane iriliğinin tohumluk üreticileri, borsa esnafı, çiftçiler, sanayiciler ve tüketiciler için önemli kalite unsurlarından biri olduğunu bildirmişlerdir. Bin tane ağırlığı (BTA)'nın buğday tanesinin irilik, dolgunluk, cılızlık durumu ile un verimi hakkında fikir vermesi açısından önemli olduğu Elgün ve ark. (2012) tarafından rapor edilmiştir. Hektolitre ağırlığı (HLA) birim hacimdeki tanelerin ağırlığı olup, un veriminin bir göstergesi olması nedeniyle de ticari bir öneme sahiptir (Elgün ve ark., 2012). Tane protein oranı (TPO) ise ticarette ve un kalitesinin tespitinde yaygın olarak kullanılan önemli bir kriterdir (Karaduman ve ark., 2015). Ekmeklik buğdayda gluten miktarı (KGL) ve kalitesinin yüksek olması ekmek yapımında aranılan önemli özelliklerden biridir. Undaki gluten miktarı ve kalitesi unun hangi ürün için kullanılabileceğinin göstergelerinden biridir (Karaduman ve Savaşlı, 2018). Ekmeklik buğdayın belirli randıman ve irilikteki un parçacıklarının sulu zayıf asitlerde, su alıp şişmesi ve belirli sürelerde çökelmeleri sonucu oluşan hacmin ölçülmesi esasına dayanan Zeleny sedimentasyon (ZSD) testi gluten kalitesinin tayininde kullanılan yöntemlerden biridir (Karaduman ve ark., 2015). Buğday sertliği (SRD) de buğdayın kullanım alanını gösteren özelliklerden biridir (Özkaya ve Özkaya, 2005). Ekmeklik kalite için sert tane yapısı istenirken, yumuşak endosperme sahip materyalde bisküvi üretiminde tercih edilmektedir (Karaduman ve ark., 2017). Tüm bu kalite özelliklerine ES uygulamalarının etkisinin bilinmesi kaliteli buğday üretimi açısından önemlidir.

Son yıllarda buğday borsasında ürünün kalite özellikleri ve kullanım alanı, ürün fiyatının belirlenmesinde giderek daha fazla önem kazanmaktadır. Özellikle gıda ve sanayi sektörünün talep ettiği ürünlere daha yüksek fiyat verildiği görülmüştür. Bu çalışmada buğday tarımında önemli yetiştirme tekniklerinden biri olarak kabul edilen ES 'nin Orta Anadolu 'da yetiştirilen bazı ekmeklik buğday çeşitlerinin kalite özellikleri üzerine etkisinin belirlenmesi hedeflenmiştir. Böylece buğday üretiminde çiftçimiz tarafından kaliteli ve yüksek talep gören ürün elde edilmesine katkı sunulması amaçlanmıştır.

\section{Materyal ve Yöntem}

Araştırmada materyal olarak Geçit Kuşağı Tarımsal Araştırma Enstitüsü Müdürlüğü (GKTAEM) tarafından tescil ettirilen ekmeklik buğday (Alpu01, Atay85, Bezostaja1, Harmankaya99, Sönmez01 ve Sultan95) çeşitleri kullanılmıştır. Denemede 4 farklı ekim sıklığı $\left(350,500,650\right.$ ve 800 tohum $\left.\mathrm{m}^{-2}\right)$ uygulaması yapılmıştır. Denemeler $39^{\circ} 46^{\prime}$ kuzey enlemi ve $30^{\circ} 24^{\prime}$ doğu boylamında olup $780 \mathrm{~m}$ yükseltiye sahip GKTAEM Eskişehir Merkez yerleşkesi deneme arazilerinde kuru (yağmura bağımlı) ve sulu şartlarda 2012-2013 ve 2013-2014 yıllarında yürütülmüştür. Tarla denemeleri tesadüf bloklarında faktoriyel deneme desene göre 3 tekerrürlü olarak kurulmuştur. Uzun yıllar yıllık yağış ortalamasının $347.5 \mathrm{~mm}$ olduğu bölgede ilk yıl $254.1 \mathrm{~mm}$, ikinci yıl ise $318.7 \mathrm{~mm}$ yıllık ortalama yağış düşmüştür. Sulu denemelere sapa kalkma (zadoks 30 ) ve başaklanma 
(zadoks 50) dönemlerinde 2 defa yağmurlama yöntemiyle sulama yapılmıştır. Kuru ve sulu deneme parselleri arasında $30 \mathrm{~m}$ izolasyon mesafesi bırakılmıştır. Denemede kullanılan tohumlar elekten geçirilerek temizlenmiş ve bin tane ağırlıkları bulunmuştur. Tohumların çimlenme gücü ve safiyeti \% 95 olarak kabul edilmiştir. Denemelerin ekimi her iki yılda da ekim ayının ikinci haftasında $5 \mathrm{~m}$ uzunluk, $1.2 \mathrm{~m}$. genişlik, $20 \mathrm{~cm}$ sıra arası olmak üzere toplam 6 $\mathrm{m}^{2}$ lik parsellere yapılmıştır. Kuru denemelere $7 \mathrm{~kg}$ $\mathrm{da}^{-1} \mathrm{~N}$ ve $7 \mathrm{~kg} \mathrm{da}^{-1} \mathrm{P}_{2} \mathrm{O}_{5}$ (Özdemir, 2011), sulu denemelere ise $12 \mathrm{~kg} \mathrm{da}^{-1} \mathrm{~N}$ ve $9 \mathrm{~kg} \mathrm{da}^{-1} \mathrm{P}_{2} \mathrm{O}_{5}$ (Çekiç ve ark., 2008) gübreleme yapılmıştır. Fosforlu gübrenin tamamı ve azotlu gübrenin yarısı ekimle birlikte makine ile verilirken, azotlu gübrenin kalan yarısı ilkbaharda sapa kalkma döneminde verilmiştir. Hastalık ve yabancı otlar izlenmiş ve geniş yapraklı yabancı otlar için kimyasal mücadele yapılmıştır. Hasat her iki yılda da temmuz ayı ortasında parsel biçerdöverleri kullanılarak yapılmıştır. Elek analizleri ICC standart 102/1 ve 103/1 protokollerine göre Pfeuffer Sortimat cihazında yapılmıştır. Örnekler (100 g), elek sallama düzeneğinde 3 dakika sallanarak elek üstlerinde çap büyüklüklerine (iri $>2.8 \mathrm{~mm}$, orta = $2.8-2.5 \mathrm{~mm}$ arası, ufak $=2.5-2.2 \mathrm{~mm}$ arası, $2.2 \mathrm{~mm}$ < elek altı) göre dört farklı elek grubuna ayrılmış ve gruplara ayrılanların miktarları yüzde (\%) olarak tespit edilmiştir (Özkaya ve Özkaya, 2005). İri ve orta grupta yer alan taneler toplanarak iri tane oranı (ITO) 'nı oluşturmuş, ufak taneler ise ufak tane oranı (UTO) grubunu oluşturmuştur. Elek altı grupta yer alan çapı $2.2 \mathrm{~mm}$ den küçük olan taneler dikkate alınmamıştır. Bin tane ağırlığı (BTA) Williams ve ark. (1986) 'a göre yapılmıştır. Hektolitre ağırlığı (HLA) elde edilen tane ürün $1 \mathrm{~L}$ hacimli Chopin nilema-litre aleti kullanılarak kg cinsinden belirlenmiştir (Anonim, 2014). Tane protein oranı (TPO) ve kuru gluten miktarı (KGL), FOSS NIRS 6500 spektroskopi cihazı kullanılarak belirlenmiştir. Cihaz protein miktarı için AACC 46.19.01 (AACCI, 2010) göre LECO FP628 ile belirlenmiş toplam azotun 5.7 faktörü ile çarpılmasıyla elde edilen sonuçlara göre ve kuru gluten miktarı için Glutamatik test cihazında elde edilen yaş özün (ICC-155) glutork cihazı ile kurutulması ile elde edilen sonuçlara göre (Anonim, 1994) kalibre edilmiştir. Zeleny sedimentasyon (ZSD) analizi ICC Metod No: 116'ya göre (Anonim, 1982) yapılmıştır. Sertlik değerleri (SRD) ölçümleri yine FOSS NIRS 6500 spektroskopi cihazında yapılmıştır. Cihaz Perten Tek Dane Karakterizasyon Sisteminde elde edilen sonuçlara göre kalibre edilmiştir. Araştırmada elde edilen veriler varyans analizine tabi tutulmuş olup incelenen faktörlerin önemlilik durumları F testine göre belirlenmiştir. Ortalamalar Asgari Önemli Fark (AÖF) testi ile karşılaştırılmıştır.

\section{Bulgular ve Tartışma}

Araştırmada incelenen parametreler varyans analizine tabi tutulmuş olup analiz sonuçları Çizelge 1 'de verilmiştir. Varyans analizi sonuçlarına göre, incelenen tüm parametrelerde kuru ve sulu çevreler arasındaki farkın önemli olduğu görülmüştür. Bu nedenle, çevreler ayrı ayrı analiz edilmiştir. Araştırmada ele alınan parametreler aşağıda açıklanmıştır.

Bu çalışmada tane iriliği iri tane oranı (ITO) ve ufak tane oranı (UTO) olmak üzere iki alt grupta incelenmiştir. Farklı ES uygulamasının genotiplerden elde edilen tane boyutlarına etkisi incelendiğinde, sadece kuru koşullarda her iki boyut grubu içinde \% 1 seviyesinde önemli bulunurken, çeşit faktörü her iki koşulda da her iki grup için \% 1 seviyesinde önemli bulunmuştur (Çizelge 1). Kuru koşullarda $2.5 \mathrm{~mm}$ den daha büyük çaptaki tanelerin oluşturduğu ітO unsurunda 350, 500 ve 650 tohum m m $^{-2}$ uygulamaları birbirlerine yakın olarak sırasıyla \% 81.47, \% 81.26 ve $\% 80.00$ değerler ile ilk grupta yer alırken 800 tohum $\mathrm{m}^{-2}$ uygulaması \% 77.83 oran ile ikinci grubu oluşturmuştur. Çapı 2.5 ile $2.2 \mathrm{~mm}$ olan tanelerden oluşan UTO parametresinde ise bunun tersi yaşanmış olup 800 tohum $\mathrm{m}^{-2}$ uygulaması \% 17.23 ile ilk grubu oluşturmuş ve diğer uygulamalar ikinci gurubu oluşturmuştur (Çizelge 2). Artan ES in tane boyutuna ters orantılı etki yapmış olup ITO 'yu azaltırken UTO 'yu artırmıştır. Çeşitler incelendiğinde ITO grubunda en yüksek değerler her iki koşul altında da Bezostaja1 ve Sönmez01 çeşitlerinden alınırken, en düşük değerler kuru koşullarda Sultan95, sulu koşullarda ise Sultan95 ve Harmankaya99 çeşitlerinden alınmıştır. UTO grubu sonuçları bu sonuca ters orantılı olarak gerçekleşmiş ve en yüksek değerler ise yine kuru koşullarda Sultan95, sulu koşullarda ise Sultan95 ve Harmankaya99 çeşitlerinden alınmıştır. Karaman ve ark. (2014) yaptıkları çalışmada, yüksek tane verimi ve un randımanı elde etmek için iri taneli tohumlar kullanılması gerektiğini belirtmişlerdir. Buğday da tane iriliği un verimi, fiziksel, kimyasal ve reolojik özellikler üzerine etkili olup un sanayicisi işleyeceği buğdayın belli bir ebatta olmasını istemektedir. Uluöz (1965)'e göre tanenin irilik ve homojenliği, un veriminin ve öğütmede kırma sayısının ya da enerji sarfının belirlenmesinde kullanılan, değirmencilik açısından önemli bir ölçüttür. Buğday tanesinin irilik ve homojenliği üzerinde etkili olan başlıca etmenler; çeşit, ekim mevsimi, uygulanan yetiştirme teknikleri, olgunlaşma sürecinde havanın gidişi, tanenin şekli ve 
büyüklüğüdür. Ekmeklik buğdayda tane iriliği $2.5 \mathrm{~mm}$ 'den büyük elek çaplarında \% 75 oranının üzerinde değer verdiğinde iri ve homojen grupta yer aldığı kabul edilir. Bu çalışmada gerek kuru gerekse sulu koşulların her ikisinde de genotiplerden \% 75 üzerinde elde edilen tane boyutu değerleri ile tanelerin homojen olduğu görülmüştür. Çizelge 3 'te verilen korelasyon tablosu değerlendirildiğinde gerek kuru gerekse sulu koşullar için ITO unsurunun TPO haricinde araştırmada incelenen diğer tüm unsurlar ile arasında önemli korelasyon bulunmuştur. Bu ilişki UTO ve SRD ile negatif yönlü, diğerleri ile pozitif yönlüdür. UTO unsurunun ise kuru koşullarda diğer tüm unsurlarla negatif yönlü ilişkisi önemli bulunurken, ZSD ile pozitif yönlü ilişkisi önemli bulunmuştur. Sulu koşullarda ise UTO unsuru ile TPO arasında ilişki bulunmazken, ZSD ve SRD ile negatif diğer unsurlar ile pozitif yönlü ilişkinin olduğu belirlenmiştir.

Çizelge 1. Kuru ve sulu koşullarda araştırmada ele alınan parametrelerin kareler ortalaması değerleri, önemlilik durumları ve varyasyon katsayıları

\begin{tabular}{|c|c|c|c|c|c|c|c|c|c|c|c|c|c|c|c|}
\hline \multirow{2}{*}{$\begin{array}{l}\text { Varyasyon } \\
\text { kaynağı }\end{array}$} & \multirow{2}{*}{ SD } & \multicolumn{4}{|c|}{ іт0 } & \multicolumn{4}{|c|}{ UTO } & \multicolumn{4}{|c|}{ BTA } & \multicolumn{2}{|c|}{ HLA } \\
\hline & & \multicolumn{2}{|c|}{ Kuru } & \multicolumn{2}{|c|}{ Sulu } & \multicolumn{2}{|c|}{ Kuru } & \multicolumn{2}{|c|}{ Sulu } & \multicolumn{2}{|c|}{ Kuru } & \multicolumn{2}{|c|}{ Sulu } & \multirow{2}{*}{$\frac{\text { Kuru }}{563.83^{* *}}$} & Sulu \\
\hline$Y_{I I}$ & 1 & \multicolumn{2}{|c|}{$833.0 * *$} & \multicolumn{2}{|c|}{$469.34^{* *}$} & \multicolumn{2}{|c|}{$143.08^{* *}$} & \multicolumn{2}{|c|}{$43.1^{* *}$} & \multicolumn{2}{|c|}{$800.6^{* *}$} & \multicolumn{2}{|c|}{$580.8^{* *}$} & & $668.52 * *$ \\
\hline Ek. sık. & 3 & \multirow{2}{*}{\multicolumn{2}{|c|}{$\begin{array}{c}100.1^{* *} \\
1980.7^{* *}\end{array}$}} & \multicolumn{2}{|c|}{2.97} & \multicolumn{2}{|c|}{$57.72 * *$} & \multicolumn{2}{|c|}{0.74} & \multicolumn{2}{|c|}{$36.4^{* *}$} & \multicolumn{2}{|c|}{$16.9 * *$} & $\begin{array}{c}563.83^{* *} \\
1.38\end{array}$ & 0.78 \\
\hline Çeşit & 5 & & & \multicolumn{2}{|c|}{$456.35^{* *}$} & \multicolumn{2}{|c|}{$1107.3^{* *}$} & \multicolumn{2}{|c|}{$237.8^{* *}$} & \multicolumn{2}{|c|}{$263.9 * *$} & \multicolumn{2}{|c|}{$130.8^{* *}$} & $62.63 * *$ & $30.03 * *$ \\
\hline $\begin{array}{l}\text { Ek.sık. } \quad x \\
\text { çeşit }\end{array}$ & 15 & 27.5 & & 5. & & 17. & $67^{*}$ & & 43* & 1.8 & & & 90 & 0.43 & 0.31 \\
\hline Hata & 92 & 16.6 & & 4. & & 9.8 & 89 & & .90 & 1.4 & & & 10 & 0.68 & 0.62 \\
\hline Genel & 143 & 120. & & 25 & & 63. & 95 & & .49 & 19. & & & .88 & 7.03 & 6.70 \\
\hline Varyasyon & SD & TPC & & & & KGL & & & & ZSD & & & & SRD & \\
\hline kaynağı & DD & Kuru & & lu & Ku & iru & Su & & $\mathrm{Ku}$ & & Su & & & & Sulu \\
\hline Yıl & 1 & $97.81 * *$ & 174. & $61^{* *}$ & 15. & $48^{* *}$ & 0.8 & & 398. & $50 * *$ & 10. & & 1041 & $.61^{* *}$ & $26727.9 * *$ \\
\hline Ek. sık. & 3 & 0.31 & 0. & 70 & 1. & 94 & 1.1 & & 14 & & $4 . \varepsilon$ & & 2.7 & $3 * *$ & 24.07 \\
\hline Çeşit & 5 & $18.28^{* *}$ & 18.7 & $5 * *$ & 42. & $8 * *$ & 26.3 & $1 * *$ & 2797 & $.9 * *$ & 1578 & $9 * *$ & 13.5 & $3 * *$ & $1021.11 * *$ \\
\hline $\begin{array}{l}\text { Ek.sık.x } \\
\text { çeşit }\end{array}$ & 15 & 0.35 & & 74 & & 63 & 0.5 & & 32 & & 16. & & & 77 & 17.28 \\
\hline Hata & 92 & 0.49 & 1. & 02 & 1. & 24 & 0.9 & & 21 & & 27. & & & 61 & 29.53 \\
\hline Genel & 143 & 2.11 & & 06 & & 02 & 1.8 & & 131 & .74 & 82. & & & .96 & 254.83 \\
\hline
\end{tabular}

*istatistiksel olarak \% 5 seviyesinde önemli; **istatistiksel olarak \% 1 seviyesinde önemli; SD: Serbestlik derecesi; VK: Varyasyon katsayısı; ITO: İri tane oranı; UTO: Ufak tane oranı; BTA: Bin tane ağırlığı; HLA: Hektolitre ağırlığı; TPO: Tane protein oranı; KGL: Kuru gluten; ZSD: Zeleny sedimentasyon; SRD: Sertlik değeri.

BTA parametresi incelendiğinde her iki koşul altında da yıllar, ekim sıklıkları ve çeşitler arası farklılıklar \% 1 seviyesinde önemli bulunmuştur (Çizelge 1). Kuru ve sulu koşullar da en fazla BTA sırasıyla 36.9 ve $44.9 \mathrm{~g}$ ile 350 tohum $\mathrm{m}^{-2}$ ES uygulamasından elde edilirken, en düşük BTA 800 tohum $\mathrm{m}^{-2}$ ES uygulamasından sırasıyla 34.6 ve $43.3 \mathrm{~g}$ olarak elde edilmiştir. Çeşitler açısından ise kuru koşullarda Bezostaja1 ve Harmankaya99 çeşitleri sırasıyla 38.4 ve $38.2 \mathrm{~g}$ ile en yüksek BTA elde edilen çeşitler olurken, en düşük BTA elde edilen çeşit 29.8 g ile Sultan95 olmuştur. Sulu koşullarda da ise en yüksek BTA elde edilen çeşit $46.1 \mathrm{~g}$ ile yine Harmankaya99 olurken en düşük BTA elde edilen çeşit $39.9 \mathrm{~g}$ ile yine Sultan95 olmuştur. BTA ortalama olarak kuru koşullarda 35.7 g olurken, sulu koşullarda
44.2 g olmuştur. Ekmeklik buğdayda BTA çoğunlukla düşen yağış miktarı ve bitkinin yetişme dönemlerine göre yağış dağılımı ve çeşidin genetiğine bağlı olarak değişebilmektedir. Hem kuru hem de sulu koşullarda benzer olarak artan ES 'yle birlikte BTA 'da düşüş meydana gelmiştir. Bu sonuç birçok araştırmacının bulduğu sonuçlarla uyumludur (Özdemir, 2011; Said ve ark., 2012; Dai ve ark., 2013). ES artışıyla birlikte BTA 'da oluşan azalmanın bitkilerde suya, ışığa ve besin elementlerine olan rekabetin artmasıyla ilişkili olduğu düşünülebilir. Araştırmada ele alınan özellikler arası ilişkilere bakıldığında BTA 'nın kuru koşullarda TPO ile ilişkisi saptanmazken, sulu koşullarda bu araştırmada ele alınan tüm unsurlarla ilişkisinin önemli olduğu tespit edilmiştir (Çizelge 3). 
Türk Tarım ve Doğa Bilimleri Dergisi 6(4): 729-736, 2019

Bu ilişki UTO ve SRD ile negatif yönlü diğerleri ile

pozitif

yönlüdür.

Çizelge 2. Incelenen özelliklerin ortalamalarının karşılaştırma tablosu ve AOF değerleri

\begin{tabular}{|c|c|c|c|c|c|c|c|c|}
\hline \multirow{2}{*}{ Ekim sıklığı } & \multicolumn{2}{|c|}{ iTO (\%) } & \multicolumn{2}{|c|}{ UTO (\%) } & \multicolumn{2}{|r|}{ BTA (g) } & \multicolumn{2}{|c|}{ HLA (kg) } \\
\hline & Kuru & Sulu & Kuru & Sulu & Kur & Sulu & Kuru & Sulu \\
\hline 350 tohum $\mathrm{m}^{-2}$ & $81.47 \mathrm{a}$ & 91.98 & $14.39 \mathrm{~b}$ & 5.74 & 36.9 & $44.9 \mathrm{a}$ & 79.6 & 81.2 \\
\hline 500 tohum m-2 & $81.26 \mathrm{a}$ & 92.03 & $14.74 b$ & 5.59 & 36.1 & $44.4 \mathrm{ab}$ & 79.7 & 81.2 \\
\hline 650 tohum m ${ }^{-2}$ & $80.00 \mathrm{a}$ & 91.65 & $15.37 b$ & 5.69 & 35.3 & $44.0 \mathrm{bc}$ & 79.7 & 80.9 \\
\hline 800 tohum m ${ }^{-2}$ & $77.83 \mathrm{~b}$ & 92.35 & $17.23 \mathrm{a}$ & 5.42 & 34.6 & $43.3 \mathrm{c}$ & 79.3 & 81.1 \\
\hline \multicolumn{9}{|l|}{ Çeşitler } \\
\hline Alpu01 & $85.16 \mathrm{~b}$ & $93.86 \mathrm{~b}$ & $11.71 \mathrm{~d}$ & $4.48 \mathrm{~b}$ & 37.2 & $45.1 \mathrm{~b}$ & $79.7 c$ & $81.5 \mathrm{~b}$ \\
\hline Atay85 & $76.55 \mathrm{~d}$ & $90.74 \mathrm{c}$ & $18.65 b$ & $6.55 \mathrm{~b}$ & 33.9 & $43.0 \mathrm{c}$ & $78.8 \mathrm{~d}$ & $80.7 \mathrm{c}$ \\
\hline Bezostaja1 & $86.47 a b$ & $96.29 \mathrm{a}$ & $11.06 \mathrm{de}$ & $2.37 d$ & 38.4 & $45.3 \mathrm{ab}$ & 80.7 b & $82.0 \mathrm{a}$ \\
\hline Harmankaya99 & $80.18 c$ & $86.56 d$ & $14.10 \mathrm{c}$ & $9.27 \mathrm{a}$ & 38.2 & $46.1 \mathrm{a}$ & 80.4 b & $81.0 \mathrm{c}$ \\
\hline Sönmez01 & $88.56 \mathrm{a}$ & $96.86 \mathrm{a}$ & $9.42 \mathrm{e}$ & $2.08 d$ & 36.8 & $45.6 \mathrm{ab}$ & $81.0 \mathrm{a}$ & $82.2 \mathrm{a}$ \\
\hline Sultan95 & $63.91 \mathrm{e}$ & $87.71 \mathrm{~d}$ & $27.66 \mathrm{a}$ & $8.92 \mathrm{a}$ & 29.8 & $39.9 \mathrm{~d}$ & $76.7 \mathrm{e}$ & $79.1 \mathrm{~d}$ \\
\hline \multicolumn{9}{|l|}{ Ortalamalar } \\
\hline Deneme & 80.14 & 92 & 15.43 & 5.61 & 35. & 44.2 & 79.6 & 81.1 \\
\hline AÖF ${ }_{E S}$ & 1.91 & 0.99 & 1.47 & 0.65 & 0.6 & 0.82 & 0.40 & 0.37 \\
\hline AÖF çeşit & 2.34 & 1.21 & 1.80 & 0.79 & 0.8 & 1.17 & 0.49 & 0.45 \\
\hline VK (0.05) & 16.32 & 2.30 & 15.21 & 24.57 & 3.38 & 3.98 & 1.04 & 0.97 \\
\hline \multirow{2}{*}{ Ekim sıklığı } & \multicolumn{2}{|c|}{ TPO (\%) } & \multicolumn{2}{|c|}{ KGL (\%) } & \multicolumn{2}{|c|}{ ZSD (ml) } & \multicolumn{2}{|c|}{ SRD (psi) } \\
\hline & Kuru & Sulu & Kuru & Sulu & Kuru & Sulu & Kuru & Sulu \\
\hline 350 tohum $\mathrm{m}^{-2}$ & 14.37 & 10.95 & $16.99 \mathrm{~b}$ & 13.48 & 42.3 & 23.07 & $69.33 a b$ & 69.54 \\
\hline 500 tohum m-2 & 14.51 & 10.92 & $17.52 \mathrm{a}$ & 13.48 & 43.7 & 22.89 & $70.04 \mathrm{a}$ & 69.38 \\
\hline 650 tohum m-2 & 14.48 & 10.64 & $17.16 a b$ & 13.40 & 43.1 & 22.89 & $66.94 b$ & 70.59 \\
\hline 800 tohum $\mathrm{m}^{-2}$ & 14.60 & 10.87 & $17.38 \mathrm{ab}$ & 13.79 & 42.3 & 22.24 & $70.95 a$ & 68.61 \\
\hline \multicolumn{9}{|l|}{ Çeşitler } \\
\hline Alpu01 & $14.49 c$ & $11.44 \mathrm{~b}$ & $17.30 \mathrm{~b}$ & $14.10 \mathrm{~b}$ & $36.0 \mathrm{c}$ & $16.27 \mathrm{de}$ & $66.34 \mathrm{~cd}$ & $65.74 \mathrm{c}$ \\
\hline Atay85 & $15.00 \mathrm{~b}$ & $10.47 \mathrm{~cd}$ & $17.89 \mathrm{~b}$ & $13.47 \mathrm{c}$ & $33.6 \mathrm{c}$ & $14.54 \mathrm{e}$ & $64.52 \mathrm{~d}$ & $60.87 d$ \\
\hline Bezostaja1 & $15.74 \mathrm{a}$ & $12.22 \mathrm{a}$ & $18.67 \mathrm{a}$ & $14.82 \mathrm{a}$ & $61.4 \mathrm{a}$ & $35.51 \mathrm{a}$ & $71.31 \mathrm{~b}$ & $71.10 \mathrm{~b}$ \\
\hline Harmankaya99 & $14.05 \mathrm{~d}$ & $10.06 \mathrm{~d}$ & $17.30 \mathrm{~b}$ & $12.78 \mathrm{~d}$ & $47.0 \mathrm{~b}$ & $24.67 c$ & $67.77 \mathrm{bcd}$ & $68.07 \mathrm{bc}$ \\
\hline Sönmez01 & $14.51 \mathrm{c}$ & $10.98 \mathrm{bc}$ & $17.65 \mathrm{~b}$ & $14.12 b$ & $46.4 \mathrm{~b}$ & $27.97 b$ & $68.31 \mathrm{~b}$ & $71.10 \mathrm{~b}$ \\
\hline Sultan95 & $13.15 \mathrm{e}$ & $9.90 \mathrm{~d}$ & $14.76 \mathrm{c}$ & $11.93 \mathrm{e}$ & $34.4 \mathrm{c}$ & $17.67 \mathrm{~d}$ & $77.78 \mathrm{a}$ & $80.31 \mathrm{a}$ \\
\hline \multicolumn{9}{|l|}{ Ortalamalar } \\
\hline Deneme & 14.49 & 10.84 & 17.26 & 13.54 & 43.1 & 22.8 & 69.32 & 69.53 \\
\hline AÖF ${ }_{E S}$ & 0.33 & 0.47 & 0.52 & 14.39 & 2.16 & 2.48 & 2.95 & 2.54 \\
\hline AÖF çeşit & 0.40 & 0.58 & 0.64 & 0.55 & 2.79 & 3.03 & 3.62 & 3.12 \\
\hline VK (0.05) & 4.80 & 9.33 & 3.38 & 5.50 & 10.67 & 23.19 & 8.96 & 7.81 \\
\hline
\end{tabular}

ITO: İri tane oranı; UTO: Ufak tane oranı; BTA: Bin tane ağırlığı; HLA: Hektolitre ağırlığı; TPO: Tane protein oranı; KGL: Kuru gluten; ZSD: Zeleny sedimentasyon; SRD: Sertlik değeri; AOF: Asgari önemli fark; VK: Varyasyon katsayısı.

HLA için yapılan varyans analiz tablosu incelendiğinde her iki koşul altında da ekim sıklıkları önemli bulunmazken, yıllar ve çeşitler arası farklılıklar \% 1 seviyesinde önemli bulunmuştur (Çizelge 1). Çeşitleri incelediğimizde kuru koşullar da en fazla HLA $81.0 \mathrm{~kg}$ ile Sönmez01 den elde edilirken sulu koşullarda sırasıyla 82.2 ve 82.0 kg ile Sönmez01 ve Bezostaja1 çeşitlerinden elde edilmiştir (Çizelge 2). En düşük HLA her iki koşulda da Sultan95 çeşidinden elde edilmiştir. HLA ortalama olarak kuru koşullarda $79.6 \mathrm{~kg}$ olurken sulu koşullarda daha yüksek gerçekleşerek $81.1 \mathrm{~kg}$ olmuştur. ES artışına bağlı olarak tane iriliği küçülen durumlarda HLA artarken tersi durumlarda ise düşer. Beslenme farklılıkları da tane iriliği ve dolaylı olarak HLA üzerine etki eder (Bulut, 2012). Korelasyon tablosunu incelediğimizde HLA 'nın kuru koşullarda araştırılan tüm unsurlar ile aralarında önemli ilişki olduğu tespit edilirken, sulu 
koşullarda ZSD haricindeki tüm unsurlarla arasında önemli ilişki bulunmuştur (Çizelge 3). Bu ilişki UTO, TPO ve SRD ile negatif yönlü, diğerleri ile pozitif yönlüdür.

TPO incelendiğinde her iki koşulda da yıllar ve çeşitler arası farklılıklar \% 1 seviyesinde önemli bulunmuştur (Çizelge 1). Çizelge 2'de görüldüğü gibi artan ES 'nin TPO 'ya etkisi istatistiksel olarak önemli düzeyde bulunmamıştır. Bu sonuç Çekiç ve ark. (2008) 'ın bulduğu sonuçlarla uyumludur. Bazı araştırmacılar ise artan ekim sıklıklarının TPO 'yu önemli derecede etkilediği ve TPO 'nun azalmasına neden olduğunu bildirmişlerdir (Chen ve ark., 2008). Çeşitler değerlendirildiğinde, en yüksek TPO kuruda \% 15.74 suluda \% 12.22 ile Bezostaja1 çeşidinden elde edilmiştir. En düşük TPO ise kuruda \% 13.15 suluda ise \% 9.90 ile Sultan 95 çeşidinden elde edilmiştir. Bu araştırmada kuru koşullarda ortalama TPO \% 14.49 olarak bulunurken, sulu koşullarda bu değer \% 10.84 olarak gerçekleşmiştir. Yürütülen birçok çalışmada bu araştırmada bulunan sonuçlara benzer olarak kuru denemelerde TPO sulu denemelerden daha yüksek bulunmuştur (Acer, 2004; Ayrancı, 2012). Çizelge 3 'te sunulan TPO ile araştırmada incelenen parametreler arasında korelasyon tablosunu incelediğimizde her iki koşulda da KGL, ZSD ve SRD arasında pozitif yönlü ilişki olduğu tespit edilmiştir. Ayrıca kuru koşullarda TPO ile UTO ve HLA arasında negatif korelasyon bulunurken, sulu koşullarda TPO ile BTA ve HLA arasında negatif korelasyon önemli bulunmuştur.

Çizelge 3. Kuru ve sulu denemelerde yer alan parametreler arası korelasyon tablosu

\begin{tabular}{|c|c|c|c|c|c|c|c|c|c|}
\hline \multicolumn{10}{|c|}{ Sulu Koşullar } \\
\hline & іTO & UTO & BTA & HLA & TPO & KGL & ZSD & SRD & \\
\hline іто & 1 & $-0.957^{* *}$ & $0.541^{* *}$ & $0.635^{* *}$ & 0.006 & $0.452 * *$ & $0.238 * *$ & $-0.372 * *$ & іто \\
\hline UTO & $-0.984 * *$ & 1 & $-0.469 * *$ & $-0.508 * *$ & -0.142 & $-0.266 * *$ & $0.244^{* *}$ & $0.177^{*}$ & UTO \\
\hline BTA & $0.808^{* *}$ & $-0.790 * *$ & 1 & $0.757^{* *}$ & $-0.266 * *$ & $0.244 * *$ & $0.177^{*}$ & $-0.603^{* *}$ & BTA \\
\hline HLA & $0.674^{* *}$ & $-0.619 * *$ & $0.839 * *$ & 1 & $-0.444 * *$ & $0.231 * *$ & 0.115 & $-0.771^{* *}$ & HLA \\
\hline TPO & 0.149 & $-0.189 *$ & -0.102 & $-0.284^{* *}$ & 1 & $0.600 * *$ & $0.371 * *$ & $0.519 * *$ & TPO \\
\hline KGL & $0.494 * *$ & $-0.473 * *$ & $0.490 * *$ & $0.431^{* *}$ & $0.568 * *$ & 1 & $0.444 * *$ & $-0.173^{*}$ & KGL \\
\hline ZSD & $0.279 * *$ & $-0.312 * *$ & $0.250 * *$ & $0.183^{*}$ & $0.477^{* *}$ & $0.417 * *$ & 1 & 0.101 & ZSD \\
\hline SRD & $-0.304 * *$ & $0.243^{* *}$ & $-0.540 * *$ & $-0.656 * *$ & $0.328 * *$ & $-0.331 * *$ & $0.165^{*}$ & 1 & SRD \\
\hline & іTO & UTO & BTA & HLA & TPO & KGL & ZSD & SRD & \\
\hline
\end{tabular}

ITO: İri tane oranı; UTO: Ufak tane oranı; BTA: Bin tane ağırlığı; HLA: Hektolitre ağırlığı; TPO: Tane protein oranı; KGL: Kuru gluten; ZSD: Zeleny sedimentasyon; SRD: Sertlik değeri.

KGL için yapılan varyans analiz tablosu incelendiğinde kuru koşullarda yıllar ve çeşitler arası farklılıklar \% 1 seviyesinde önemli bulunurken, sulu koşullarda yalnızca çeşitler arası farklılıklar önemli bulunmuştur (Çizelge 1 ). Çeşitler değerlendirildiğinde, en yüksek KGL kuru ve sulu koşullarda sırasıyla \% 18.67 ve \% 14.82 ile Bezostaja1 çeşidinden elde edilmiştir. En düşük KGL ise kuruda \% 14.76 suluda ise \% 11.93 ile Sultan 95 çeşidinden elde edilmiştir (Çizelge 2). Bu araştırmada kuru koşullarda ortalama KGL \%17.26 olarak bulunurken, sulu koşullarda bu değer \% 13.54 olarak gerçekleşmiştir. Gluten, ekmeklik buğdayda proteinin $\%$ 80-85'ini oluşturur ve miktarı ise protein miktarı ile doğru orantılıdır (Karaduman, 2013). KGL ile araştırmada incelenen diğer tüm parametreler arasında hem kuru hem de sulu koşullarda ilişki önemli bulunmuş olup, bu ilişkinin UTO ve SRD ile negatif yönlü diğerleri ile pozitif yönlü olduğu saptanmıştır (Çizelge 3).
ZSD değeri incelendiğinde kuru koşullarda yıllar ve çeşitler arası farklılıklar \% 1 seviyesinde önemli bulunurken, sulu koşullarda yalnızca çeşitler arası farklılıklar önemli bulunmuştur (Çizelge 1 ). Çeşitler değerlendirildiğinde, en yüksek ZSD kuru ve sulu koşullarda sırasıyla 61.4 ve $35.5 \mathrm{ml}$ ile Bezostaja1 çeşidinden elde edilmiştir. En düşük ZSD ise kuruda 33.6 suluda ise 14.5 ile Atay 85 çeşidinden elde edilmiştir (Çizelge 2). Bu araştırmada kuru koşullarda ortalama ZSD $43.1 \mathrm{ml}$ olarak bulunurken, sulu koşullarda bu değer $22.8 \mathrm{ml}$ olarak gerçekleşmiştir. Sedimentasyon değeri çevreye göre çeşitten daha fazla etkilenmektedir (Koçak ve ark., 1992). Elgün ve ark. (2012) yüksek sedimentasyon değeri olan unlardan yapılan ekmeklerin hacimlerinin de yüksek olduğunu birdirmişlerdir. Islah programlarında diğer parametrelerle birlikte ZSD değerinin yüksek olması arzu edilmektedir (Karaduman ve ark., 2015). Kuru koşullarda ZSD ile UTO arasında negatif araştırmada incelenen diğer 
tüm parametreler arasında hem kuru hem de sulu koşullarda ilişki önemli bulunmuş olup bu ilişki UTO ve SRD ile negatif yönlü diğerleri ile pozitif yönlüdür (Çizelge 3).

SRD için yapılan varyans analiz tablosu incelendiğinde için kuru koşullarda yıllar, ekim sıklıkları ve çeşitler arası farklılıklar \% 1 seviyesinde önemli bulunurken sulu koşullarda yıllar ve çeşitler arası farklılıklar önemli bulunmuştur (Çizelge 1). Ekim sıklıkları değerlendirildiğinde en düşük SRD 650 tohum $\mathrm{m}^{-2}$ uygulamasından elde edilirken diğer uygulamalar birbiriyle aynı grupta yer almışlardır. Çeşitler değerlendirildiğinde, en yüksek SRD kuru ve sulu koşullarda sırasıyla 77.78 ve 80.31 ile Sultan95 çeşidinden elde- edilmiştir. En düşük SRD ise kuruda 64.52 suluda ise 60.87 ile Atay85 çeşidinden elde edilmiştir. Bu araştırmada kuru koşullarda ortalama SRD 69.32 olarak bulunurken, sulu koşullarda bu değer 69.53 olarak gerçekleşmiştir (Çizelge 2). Tane sertliğinin genetik yapıya bağlı olduğu ve tane endospermindeki proteinler ve nişasta arasındaki bağlantının sonucu olarak ortaya çıktığı bilinmektedir (Özkaya ve Özkaya, 2005). Tane sertliği buğdayın öğütme, pişirme ve son kullanım kalitesini etkileyen önemli bir faktördür ve öğütme enerjisi, un partikül büyüklüğü, un verimi, nişasta zedelenmesi, unun su absorpsiyonu, hamurun gelişme süresi ve uzama yeteneğini etkiler (Morris, 2002). Tane sertliği büyük oranda genetik yapıya bağlıdır ve ekmeklik buğdayda tane endosperm yapısının istenilen sertlikte olması arzu edilmektedir (Karaduman ve ark., 2017). Sertlik değeri ıslah programlarında değerlendirilmesi gereken önemli bir parametredir. Tane sertlik değeri un, öğütme, gluten kalite ve nişasta özellikleri ile önemli korelasyon vermiştir (Karaduman ve Ercan, 2014). SRD ile kuru koşullarda araştırmada incelenen tüm parametreler arasında, sulu koşullarda ise ZSD haricindeki tüm parametrelerle korelasyon önemli bulunmuştur (Çizelge 3). Her iki koşulda da SRD ile UTO ve TPO arasındaki ilişki negatif yönlü, diğerleri ile pozitif yönlüdür.

\section{Sonuç ve Öneriler}

Artan ekim sıklıkları tane boyutuna ters orantılı etki yapmış olup ITO grubunun oranını azaltırken UTO grubunu artırmıştır. Hem kuru hem de sulu koşullarda benzer olarak artan ES 'yle birlikte BTA 'da düşüş meydana gelirken 350 tohum $\mathrm{m}^{-2}$ uygulamasından en yüksek BTA ve іTO değeri elde edilmiştir. Yine artan ES 'nin HLA, TPO, KGL ve ZSD parametrelerine her iki koşul altında da etkisi önemli bulunmamıştır. Sönmez01 en yüksek ITO, HLA değeri açısından, Bezostaja1 ise BTA, TPO, KGL, ZSD açısından öne çıkan çeşitler olurken Sultan95 UTO ve SRD açısından öne çıkan çeşit olmuştur. Özellikler arası ilişkiler değerlendirildiğinde gerek kuru gerekse sulu koşullar için ITO unsurunun TPO haricinde araştırmada incelenen diğer tüm unsurlar ile arasında önemli korelasyon bulunmuştur.

a: Çalışmanın verileri sorumlu yazarın doktora tezinden alınmıştır.

\section{Kaynaklar}

Acer, S. 2004. Bazı Makarnalık Buğday Çeşitlerinin Verim ve Kalite Özellikleri Üzerine Farklı Sulama Zamanları ile Azot Dozlarının Etkisi. Ankara Üniversitesi, Fen Bilimleri Enstitüsü. Tarla Bitkileri ABD, Doktora Tezi, Ankara.

Akinci, C., Yildirim, M., Bahar, B. 2008. The effects of seed size on emergence and yield of durum wheat. Journal of Food Agriculture and Environment, 6(2): 234.

Alexandratos, N., Bruinsma, J. 2012. World Agriculture Towards. 2030/2050: the 2012 Revision (Vol. 12, No. 3). FAO, Rome: ESA Working Paper.

AACCI (American Association of Cereal Chemists International), 2010. AACC Approved Methods of 46-19.01, St. Paul, MN, USA.

Anonim, 1982. ICC-Standard No:110/1 ICC-Standard No:116 and 104. International Association for Cereal Chemistry.

Anonim, 1994. ICC Standart 1994. ICC No: 155. Determination of Wet Gluten Quality and Quantity (Gluten Index ac to Pretend) of Whole Wheat Meal and Wheat Flour.

Anonim, 2014. AFNOR NF V03-719 (only the Nilemaliter) and ISO 7971/2 standards. (www.chopin.fr) (Erişim tarihi 29.09.2018).

Anonim. 2018a. World Population Projected to Reach 9.7 Billion by 2050. (https://www.un.org) (Erişim tarihi: 19.01.2019).

Anonim, 2018b. Nüfus Projeksiyonları, 2018-2080. (http://www.tuik.gov.tr) (Erişim tarihi: 19.01.2019).

Anonim, 2019. (www.tuik.gov.tr) (Erişim tarihi: 29.05.2019).

Aydoğan, S., Şahin, M., Akçacık, A.G., Yakışır, E. 2015. Farklı Tane iriliğinin ekmeklik buğday kalitesine etkisi. Selçuk Tarım Bilimleri Dergisi, 1(1): 27-33.

Ayrancı, R. 2012. Farklı Kuraklık Tiplerinde Ekmeklik Buğday Genotiplerinin Fizyolojik, Morfolojik, Verim ve Kalite Özellikleri Yönüyle Islahta Kullanılabilecek Uygun Parametrelerin 
Belirlenmesi. Selçuk Üniversitesi, Fen Bilimleri Enstitüsü, Tarla Bitkileri Anabilim Dalı, Doktora Tezi, Konya.

Bulut, S. 2012. Ekmeklik buğdayda kalite. Erciyes Ü., Fen Bil. Enst., Fen Bil. Der., 28(5): 441-446.

Chen, C., Neill, K., Wichman, D., Westcott, M. 2008. Hard Red spring wheat response to row spacing, seeding rate, and nitrogen. Agronomy Journal, 100: 1296-1302.

Çekiç, C., Savaşlı, E., Dayıoğlu, R., Önder, O., Karaduman, Y., Avcıoğlu, R. 2008. Ekmeklik buğdayda (Triticum aestivum L.) Ekim zamanı ve sıklığı ile kalite kriterleri arasındaki ilişkilerin belirlenmesi. Türkiye Tahıl Sempozyumu, Konya.

Dai, X., Zhou, X., Jia, D., Xiao, L., Kong, H., He, M. 2013. Managing the seeding rate to improve nitrogen-use efficiency of winter wheat. Field Crops Research, 154: 100-109.

Elgün, A., Ertugay, Z., Certel, M. Kotancilar, H.G. 2012. Tahıl ve Ürünlerinde Analitik Kalite Kontrolü ve Laboratuvar Uygulama Kılavuzu. 4. Bas. Atatürk Ünv. Yayın No: 867.

Karaduman, Y. 2013. Seçilmiş yumuşak Ekmeklik Buğday Hatlarında Bisküvilik Kalite Özelliklerinin Araştırılması. A.Ü. Fen Bilimleri Enstitüsü, Gıda Müh. A.B.D., Doktora Tezi, Ankara.

Karaduman, Y., Ercan, R. 2014. Using particle size index hardness in biscuit wheat selection. $25^{\text {th }}$ International Scientific-Experts Congress On Agriculture and Food Industry, Book of Abstracts, 25-27 September 2014, p.44, İzmir, Turkey.

Karaduman, Y., Akın, A., Türkölmez, S., Tunca, Yüksel, S. 2015. Ileri kademe ekmeklik buğday hatlarının bazı teknolojik kalite özelliklerinin değerlendirilmesi. TARM Araştırma Enstitüsü Dergisi, 24(1): 24-29.

Karaduman, Y., Akın, A., Türkölmez, S., Tunca, Z.S., Belen, S.O., Server, B.B. 2017. Ekmeklik buğday ıslah programında teknolojik kalite parametreleri yönü ile yapılan değerlendirmeler. XII. Tarla Bitkileri Kongresi, Poster Bildiri, Kahramanmaraş.

Karaduman, Y., Savaslı, E. 2018. Some practices using glutopeak tester: A High shear gluten quality evaluation method. $13^{\text {th }}$ Gluten Workshop. Poster Presentation. Book of Abstracts, p.115, Mexico City-Mexico.

Karaman, M., Aktaş, H., Kendal, E., Erdemci, i., Tekdal, S. 2014. Bazı ekmeklik buğday çeşitlerinde tohum iriliği ile verim ve kalite parametreleri arasındaki ilişkinin değerlendirilmesi. Uluslararası Türkiye 5 . Tohumculuk Kong. ve Sek. İş Forumu.

Koçak, N., Atlı, A., Karababa, E., Tuncer, T. 1992. Macar-Yugoslav (MAYEB) ekmeklik buğday çeşitlerinin kalite özellikleri üzerine araştırmalar. TARM Araştırma Enstitüsü Dergisi, 1(1).

Morris, C.F. 2002. Puroindolines: the molecular genetic basis of wheat grain hardness. Plant Molecular Biology, 48(5-6): 633-647.

Özdemir, S. 2011. Farklı Lokasyonlarda Ekilen Buğday Çeşitlerinin Optimum Ekim Sıklığının Belirlenmesi, ESOGÜ Fen Bilimleri Enstitüsü, Yüksek Lisans Tezi.

Özkaya, H., Özkaya, B. 2005. Tahıl ve Ürünleri Analiz Yöntemleri. AÜ Mühendislik Fak. Gıda Müh. Bölümü Gıda Teknolojisi Yayınları No.30, Ankara.

Said, A., Gul, H., Saeed, B., Haleema, B., Badshah, N.L., Parveen, L. 2012. Response of wheat to different planting dates and seeding rates for yield and yield components. ARPN Journal of Agricultural and Biological Science, 7(2): 138140.

Uluöz, M. 1965. Buğday Un ve Ekmek Analiz Metotları. EÜ Ziraat Fak. Yay. No: 57.

Williams, P.C., El-Haramein, F.J., Nakkaoul, H., Rihawi, S. 1986. Crop Quality Evaluation Methods and Guidelines. ICARDA. 142 p. Aleppo, Syria. 